\title{
THE EFFECT OF DIFFERENT RETINA DISEASES ON CHOLESTEROL AND FATTY ACID CONTENT OF SILICONE OIL FROM VITRECTOMIZED EYES
}

\author{
HULYA GÜNGEL ${ }^{1}$, SERIFE EVRIM KEPEKCI TEKKELI ${ }^{*}$ \\ ${ }^{1}$ Istanbul Training and Research Hospital, Clinic of Ophthalmology, Fatih, 34098 Istanbul, Turkey \\ ${ }^{2}$ Bezmialem Vakif University, Faculty of Pharmacy, Department of Analytical Chemistry, Fatih, 34093 Istanbul, Turkey \\ "Address correspondence and reprint requests to Tekkeli Kepekci S. Evrim (PhD Pharm) \\ Bezmialem Vakif University, Faculty of Pharmacy, Department of Analytical Chemistry, 34093 Fatih-Istanbul- Turkey
}

\begin{abstract}
The differences of cholesterol and fatty acid content of silicone oils that were removed from vitrectomized eyes due to different retinal diseases were investigated. The silicone oils were removed from 25 cases after 4-8 months and classified in two groups; Group A consists of 11 patients who had undergone pars plana vitrectomy combined with phacoemulsification and intraocular lens implantation due to diabetic tractional retinal detachment and Group B consists of 14 patients who was treated for phakic primary rhegmatogenous retinal detachment. The removed material from vitrectomized eyes in Group A was opacified and gelatinous on the other hand in Group B it was transparent. Hexan extracts were prepared from liquid and emulsified phases. The extracts were taken into vials, after that, hexane was removed. The chemical structure of each extracted material was investigated by spectroscopic techniques. The concentration of unsaturated fatty acids (FAs) in both groups were compared statistically. In conclusion, in Group A, epoxy and hydroxy-epoxy FAs were determined. The mean amount of unsaturated FAs in Group A was significantly lower than Group B. Cholesterol was not detected in any samples. The type of FAs in removed silicone oils may differ depending on the oxidative stress of retina.
\end{abstract}

Keywords: fatty acids, FTIR, silicone, epoxigenases

\section{INTRODUCTION}

Total fat content in retina, consists of different fatty acids (FAs); saturated FAs and unsaturated FAs, such as n-3 and n-6 polyunsaturated FAs. They have different biological effects. The studies reported that palmitic acid, stearic acid, oleic acid, arachidonic acid, maleic acid, docosahexaenoic acid (DHA) were the major FAs in human retinal tissue [1-3]. The FAs composition of interphotoreceptor matrix, retinal pigment epithelium (RPE) and sensoriel retina are different from each other [4,5]. RPE expresses the enzymatic machinery for synthesizing lipoprotein-like particles $[6,7]$, suggesting that it can export lipids. It is suggested that cholesteryl esters are important sources of FAs entering the retina [5].

In literature, there are many valuable studies that explain the effects of silicone oil on the retina and optic nerve [1-5]. These studies report that the silicone oil (polidimethylsiloxane) migrated into optic nerve by active transportation [8], had negative effect on retinal microcirculation [9] and mechanical effect on retinal pigment epithelium [10]. This could be a reason for the loss of myelinated nerve fibres of the optic nevre [11]. Also, thinning of inner retinal layers [12] and that was engulfed by Muller cells [13] which could be the cause of breakdown of the blood-aqueous barrier [14]. At the same time, silicone oil is a barrier for oxygen transportation from the anterior to the posterior segment [15].

Polidimethylsiloxane is a polydispersed synthetic polymer consisting of a mixture of different linear chain lengths which may also contain linear and cyclic species of lower molecular weights, so called as low molecular weight components (LMWC), widely used as by-products [16-19]. Impurities of polidimethylsiloxane are possibly cause emulsification and intraocular complications [20-22]. It is known that silicone is a hydrophobic material and lipids can easily be dissolved in silicone oil. This is the reason of retinol, cholesterole, FAs and metil esters existence [17,18,23]. Additionally, lipids facilitate the emulsification of silicone oil. Emulsification of silicone oil occurs in the interface between silicone oil and retinal tissue.

In the removed and stored $\left(a t+4^{\circ} \mathrm{C}\right)$ in silicone oil samples, a lucid water phase at the bottom, transparent silicone phase on a top layer and a yellowish emulsified phase in the middle were observed. The aim of this study is to investigate the effect of the ongoing retinal diseases on FAs and cholesterol content of the removed silicone oils.

For this purpose, a study was conducted with silicone oils removed from 25 cases. These cases were classified in two groups; Group A consists of 11 patients who had undergone pars plana vitrectomy combined with phacoemulsification and intraocular lens implantation due to diabetic tractional retinal detachment and Group B consists of 14 patients who was treated for phakic primary rhegmatogenous retinal detachment. Vitrectomy was carried out between 4-8 months after treatment procedures. Hexan extracts were prepared from liquid and emulsified phases from 25 samples. The extracts were taken into vials, after that, hexane was removed. The chemical structure of each extracted material was investigated by fourier transform infrared spectroscopy (FT-IR), gas chromatography-flame ionization dedector (GC-FID), ${ }^{1} \mathrm{H}$ NMR and ${ }^{13} \mathrm{C}$ NMR spectroscopy techniques. The unsaturated FAs in both groups were compared statistically. The presence of FAs were investigated with FTIR ve NMR spectroscopy, the type of FAs and their relative quantity was determined by GC and the existence of cholesterol is revealed according GC and NMR spectroscopy.

The effect of different retina diseases on cholesterol and fatty acid content of removed silicone oil were discussed.

\section{MATERIALS AND METHODS}

\section{General Procedure}

This study complies with the Declaration of Helsinki [24] including current revisions and Good Clinical Practice guidelines [25,26]. The procedures followed were in accordance with institutional guidelines and all subjects gave written informed consent before each surgery.

Silicone oil (polydimethylsiloxane [Ophta-Sil ${ }^{\mathrm{TM}} 1000$ ]) removed from 25 cases which include 13 male, 12 female volunteers between 56 and 73 years old. 11 of them had undergone 23 gauge pars plana vitrectomy due to diabetic tractional detachment (Group A) and 14 of them had primary rhegmatogenous retinal detachment with proliferative vitreoretinopati grade $\leq \mathrm{C} 2$ (Group B) in Beyoglu Training and Research Hospital $4^{\text {th }}$ Clinic of Ophthalmology.

Both preoperative and postoperative routine ophthalmologic examinations of all cases were recorded. 23 gauge pars plana vitrectomy combined with phacoemulsification was applied to Group A cases. Laser treatment was applied around the retinal degeneration and tears in Group $\mathrm{B}$ and also inadequate panretinal photocoagulation to diabetic tractional retinal detachment was completed in the same surgery.

4-8 months later, silicone oils were removed from the reattached retinas. The visual acuity and fundus examinations of all cases after one month from the removal of silicone oils were recorded.

Removal process of silicone oil from the eye was carried out with a vacuum syringe with a 23 gauge blunt needle. An automated vacuum oil pump was activated by a foot pedal. An infusing irrigating solution was connected to 23 gauge cannula and placed through another sclerotomy in an opposite quadrant.

All the silicone oils were removed from sclerotomy by means of serum (Isolyte ${ }^{\circledR}$, Eczacıbaşı-Baxter, Turkey). In each sample including serum and silicone oil was taken as $10 \mathrm{~mL}$. The removed samples were kept at $+4^{\circ} \mathrm{C}$ in tubes. Emulsified phases were extracted and separated from water by shaking 
for 15 minutes in separator funnel with teflon tap and stopper for 3 times with $10 \mathrm{~mL}$ hexane. It was seen that the opacified and gelatinous material did not dissolve in hexane. Hexane extracts were put in separate vials, after that hexane was removed. Firstly, fatty residue was investigated by infrared spectroscopy.

\section{Analysis of Hexane Extracts}

Fourier Transformed Infrared Spectroscopy

FT-IR spectrum was recorded on Perkin Elmer Spectrum 100 ATR-FTIR spectrophotometer, the silicone oil and lipids were characterized by ATR-FTIR technique [27]. The chemical structure of chlolesterol was shown in Fig. 1.

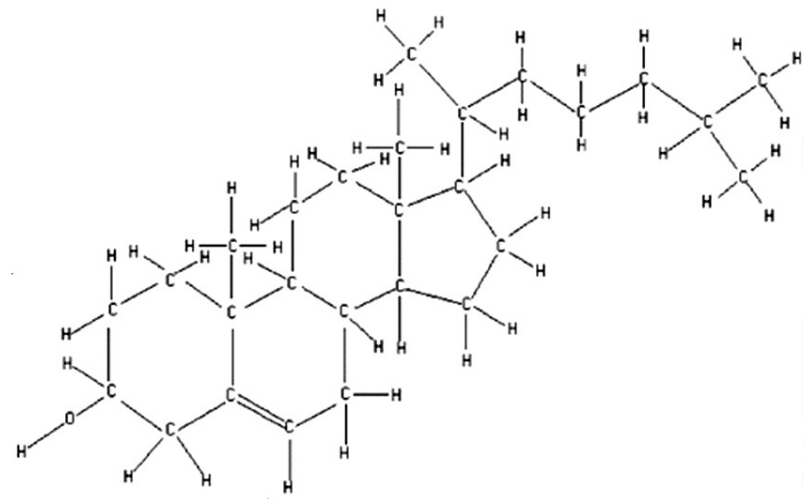

Fig. 1 Open formula of cholesterol

\section{Gas Chromatography}

Gas chromatography were used for the same extracts with IUPAC ID19 $6^{\text {th }}$ edition method in order to determine the types of FAs [28]. Capillary column was used with $30 \mathrm{~m}$ lenght and $0.3 \mathrm{~mm}$ internal diameter, coated with methylpolysiloxane with the film thickness $0.2 \mu \mathrm{m}$. FID dedector was used. Electric oven regulated at $110^{\circ} \mathrm{C}$. The presence of cholesterol was also investigated by GC in the same extracts by using external standard.

The mean of unsaturated fatty acid ratios in the extracts of two groups were determined and were compared by 'Mann-Whitney U test'.

${ }^{1} \mathrm{H}$ NMR and ${ }^{13} \mathrm{C}$ NMR Spectroscopy

${ }^{1} \mathrm{H}$ NMR Spectroscopy

${ }^{1} \mathrm{H}$ NMR spectra were performed on a spectrometer Varian Unity Inova $500 \mathrm{MHz}$ spectrometer. The spectra was recorded at room temperature with a 5 -mm PFG indirect detection ${ }^{1} \mathrm{H}-{ }^{19} \mathrm{~F}\left({ }^{15} \mathrm{~N}-{ }^{31} \mathrm{P}\right)$ probe. Samples were dissolved in $\mathrm{CDCl}_{3}$. The ${ }^{1} \mathrm{D}$ proton NMR spectra was acquired using S2PUL sequence ( $32 \mathrm{~K}$ data points, acquisition time $1.892 \mathrm{~s}$, pulse width $6.65 \mu \mathrm{s}$, repetition delay $2 \mathrm{~s}, 1024$ scans)

${ }^{13} \mathrm{C}$ NMR spectroscopy

The ${ }^{13} \mathrm{C}$ NMR spectra were acquired using S2PUL sequence in decoupling mode $(32 \mathrm{~K}$ data points, acquisition time $0.522 \mathrm{~s}$, pulse width $4.5 \mu \mathrm{s}$, repetition delay $5 \mathrm{~s}, 9292$ scans) and solvent $\mathrm{CDCl}_{3}$.

\section{RESULTS AND DISCUSSION}

\section{Visual Acuity Measurement}

The preoperative visual acuities were between 1.00 $3.10 \log$ MAR $(2.23 \pm 0.86 \log$ MAR $)$ in Group A and were between $0.25-3.10$ logMAR $(2.46 \pm 0.99 \log$ MAR $)$ in Group B. According to last postoperative examination, the visual acuities were between 0.15-3.10 $\log$ MAR $(1.03 \pm 0.78 \log$ MAR $)$ in Group A and were between $0.00-3.10 \log$ MAR $(0.73 \pm 0.59 \log M A R)$ in Group B. In both groups the results were statistically significant $(\mathrm{p}=0.05)$. All cases were pseudophakic and their intraocular pressure were between $11 \mathrm{mmHg}$ and $22 \mathrm{mmHg}$ without medication.

FT-IR Spectroscopic Data of Hexane Extracts

The FT-IR spectroscopic findings of Group A and Group B were listed in Table 1 and 2. The FT-IR spectra of Group A and B were shown in Fig. 2 and Fig. 3. The presence of absorption peaks at $1745 \mathrm{~cm}^{-1}$ in FT-IR spectra indicated the presence of esterified FAs in all cases. The extracts of Group A showed the presence of epoxy/hydroxy-epoxy FAs addition to esterified FAs.
Table 1 The FT-IR spectra of vibrations of silicone oil and fatty acids.

\begin{tabular}{|c|c|}
\hline Wavenumber & Vibration charateristics \\
\hline $3322 \mathrm{~cm}^{-1}$ & $\mathrm{OH}$ stretching mode of water \\
\hline $2963 \mathrm{~cm}^{-1}$ & $\mathrm{CH}_{3}$ symmetric stretch \\
\hline $2921 \mathrm{~cm}^{-1}$ & $\mathrm{CH}_{2}$ asymmetric stretch: mainly lipids \\
\hline $2854 \mathrm{~cm}^{-1}$ & $\mathrm{CH}_{2}$ symmetric stretch: mainly lipids \\
\hline $1745 \mathrm{~cm}^{-1}$ & $\mathrm{C}=\mathrm{O}$ asymmetrical stretch: fatty acid ester group \\
\hline $1637 \mathrm{~cm}^{-1}$ & $\mathrm{C}=\mathrm{C}$ symmetrical stretch: fatty acid ester group \\
\hline $1457 \mathrm{~cm}^{-1}$ & $\mathrm{CH}_{2}$ bending: mainly lipids \\
\hline $1258 \mathrm{~cm}^{-1}$ & $\mathrm{CH}_{3}$ symmetric deformation of Si-CH \\
\hline $1081 \mathrm{~cm}^{-1}$ & Si-O-Si stretching (silicone) \\
\hline $1009 \mathrm{~cm}^{-1}$ & Si-O-Si stretching (silicone) \\
\hline $786 \mathrm{~cm}^{-1}$ & Si-C stretching (silicone) \\
\hline
\end{tabular}

Table 2 Functional groups and mode of vibration from the FTIR spectra of pure cholesterol.

\begin{tabular}{|c|c|}
\hline Wavenumber & Functional groups \\
\hline $680 \mathrm{~cm}^{-1}$ & The $\mathrm{C}=\mathrm{C}$ ring Bending \\
\hline $\begin{array}{l}680 \mathrm{~cm}^{-1} \\
769 \mathrm{~cm}^{-1}\end{array}$ & $\begin{array}{l}\text { Alkenes } \mathrm{C}-\mathrm{H} \text { out-of-plane vibrations between } 650 \\
\text { and } 1000 \mathrm{~cm}^{-1}\end{array}$ \\
\hline \multicolumn{2}{|l|}{ Bending } \\
\hline $\begin{array}{l}859 \mathrm{~cm}^{-1} \\
932 \mathrm{~cm}^{-1} \\
1037 \mathrm{~cm}^{-1}\end{array}$ & $\mathrm{C}-\mathrm{C}$ backbone vibration (weak) stretching \\
\hline $\begin{array}{l}1037 \mathrm{~cm}^{-1} \\
1219 \mathrm{~cm}^{-1}\end{array}$ & $\mathrm{C}-\mathrm{O}$ vibration stretching \\
\hline $\begin{array}{l}1219 \mathrm{~cm}^{-1} \\
1372 \mathrm{~cm}^{-1}\end{array}$ & $\begin{array}{l}\text { Interaction of } \mathrm{O}-\mathrm{H} \text { bending and } \mathrm{C}-\mathrm{O} \text { stretching in } \\
\mathrm{C}-\mathrm{O}-\mathrm{H} \text { group }\end{array}$ \\
\hline \multicolumn{2}{|c|}{ Bending, stretching } \\
\hline $1443 \mathrm{~cm}^{-1}$ & $\begin{array}{l}\mathrm{C}=\mathrm{C} \text { vibration, stretching, } \\
\mathrm{CH}_{2} \text { (C-H bond ) vibration, bending }\end{array}$ \\
\hline $1546 \mathrm{~cm}^{-1}$ & Unknown vibration \\
\hline $\begin{array}{l}2882 \mathrm{~cm}^{-1} \\
2948 \mathrm{~cm}^{-1}\end{array}$ & $\begin{array}{l}\text { Asymmetric vibrations of } \mathrm{C}-\mathrm{H} \text { bonds of methyl } \\
\text { groups of } \\
\text { Cholesterol structure }\end{array}$ \\
\hline
\end{tabular}

Opacified and gelatinous material were not mixed into the extract after FTIR could not be applied to the spectroscopy in order to avoid contamination. The remaining portion was examined by GC.

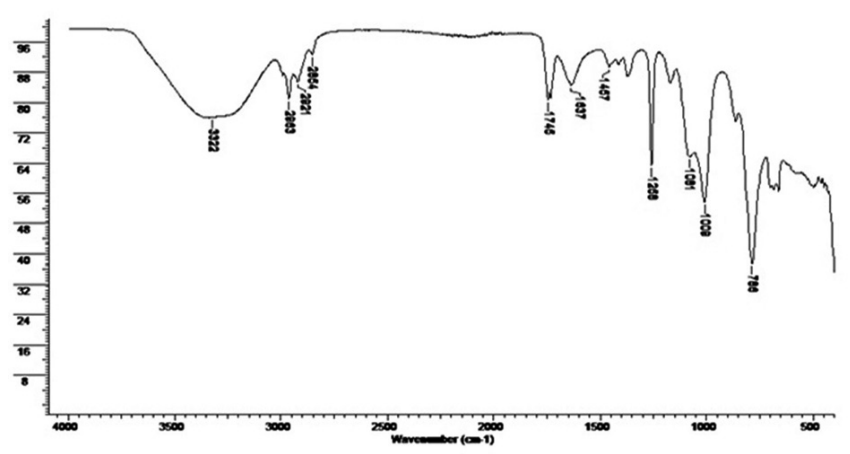

Fig. 2 The IR spectra of Group A 


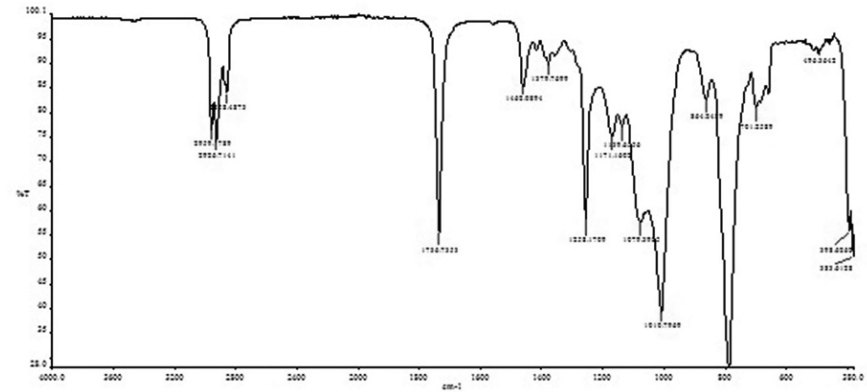

Fig. 3 The IR spectra of Group B.

GC Results of the Hexane Extracts

$\mathrm{GC}$ features of the hexane extracts: The ratio of unsaturated FAs was $7.02 \%$ in the extract sample of Group A and $19.33 \%$ in that of Group B. The arrythmetical mean of these ratios were $6.74 \% \pm 0.65(6.08-7.52 \%)$ in Group $\mathrm{A}$ and $21.22 \% \pm 1.67(19.33-23.14 \%)$ in Group B .The difference between the mean ratio of unsaturated FAs was statistically important $(\mathrm{p}=0,05)$. Cholesterol was not detected by GC-FID in any of the samples obtained by hexane extraction from silicone samples. GC data are listed in Table 3 and 4.

Table 3 The GC sample for five extracts of Group B.

\begin{tabular}{|c|c|c|c|c|}
\hline Peak & Component name & Time $(\min )$. & Area & Area \% \\
\hline 1 & Capric acid & 6.789 & 379.06 & 57.88 \\
\hline 2 & Myristic acid & 11.000 & 132.66 & 20.26 \\
\hline 3 & Myristoleic acid & 12.697 & 8.37 & 1.28 \\
\hline 4 & Palmiteloic acid & 15.444 & 27.28 & 4.17 \\
\hline 5 & Oleic acid & 18.027 & 36.31 & 5.59 \\
\hline 6 & Linoleic acid & 20.455 & 26.84 & 4.10 \\
\hline 7 & Docosadienoic acid & 22.768 & 27.42 & 4.19 \\
\hline
\end{tabular}

Table 4 The GC sample for four extracts of Group A.

\begin{tabular}{|c|c|c|c|c|}
\hline Peak & $\begin{array}{l}\text { Component } \\
\text { name }\end{array}$ & Time (min.) & Area & Area $\%$ \\
\hline 1 & & 3.622 & 807.14 & 8.76 \\
\hline 2 & Butyric acid & 3.752 & 161.33 & 1.75 \\
\hline 3 & Caproic acid & 4.434 & 1248.46 & 13.54 \\
\hline 4 & Caprylic acid & 6.212 & 3.622 & 39.30 \\
\hline 5 & Capric acid & 6.782 & 118.34 & 1.28 \\
\hline 6 & Lauric acid & 9.122 & 3333.77 & 4.52 \\
\hline 7 & $\begin{array}{l}\text { Tridacylic } \\
\text { acid }\end{array}$ & 10.404 & 1709.47 & 2.32 \\
\hline 8 & $\begin{array}{l}\text { Myristoleic } \\
\text { acid }\end{array}$ & 12.565 & 549.82 & 5.96 \\
\hline 9 & $\begin{array}{c}\text { Heptadecanoic } \\
\text { acid }\end{array}$ & 15.713 & 206.26 & 2.24 \\
\hline 10 & $\begin{array}{l}\text { Linoleadic } \\
\text { acid }\end{array}$ & 18.702 & 144.23 & 1.56 \\
\hline 11 & $\begin{array}{l}\text { Lignoceric } \\
\text { acid }\end{array}$ & 24.559 & 277.85 & 3.01 \\
\hline 12 & & 25.477 & 16.67 & 2.55 \\
\hline
\end{tabular}

NMR Spectroscopic Data

${ }^{1} \mathrm{H}$ NMR Spectroscopic Data

${ }^{1} \mathrm{H}$ NMR spectroscopic findings of FAs were between $0.0-3.00 \mathrm{ppm}$ for Group B was shown in Fig. 4.

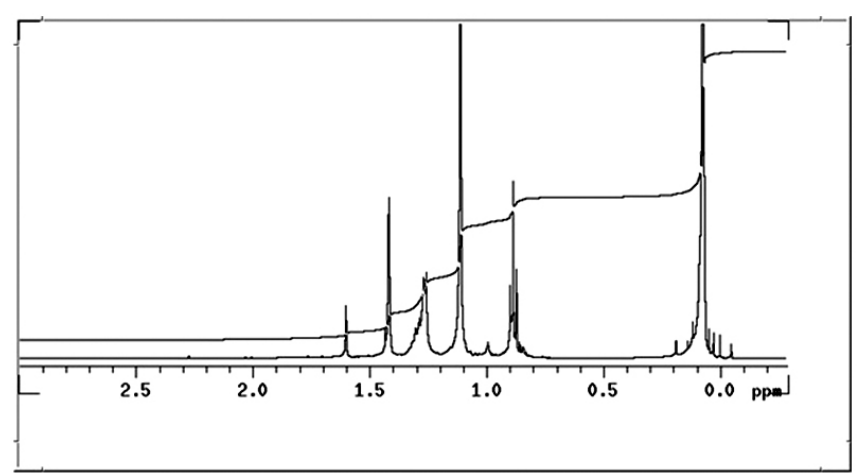

Fig. 4 A sample of ${ }^{1} \mathrm{H}$ NMR spectroscopic findings between 0-3.00 ppm of Group B

${ }^{13} \mathrm{C}$ NMR Spectroscopic Data

Any C signal between 120-130 ppm was not observed, so we can conclude that the absence of cholesterol may be observed in both groups' extracts (Fig. 5). ${ }^{13} \mathrm{C}$ NMR spectroscopic findings of FAs is shown in Fig 6.

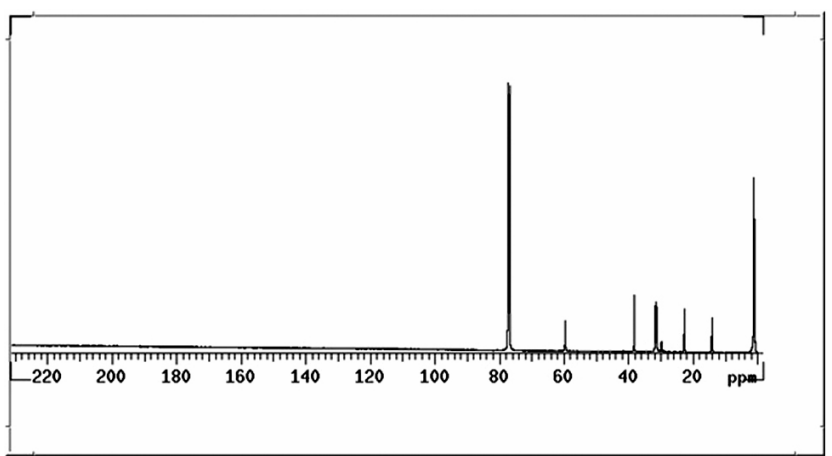

Fig. 5 A sample of ${ }^{13} \mathrm{C}$ NMR spectroscopic findings of Group B.

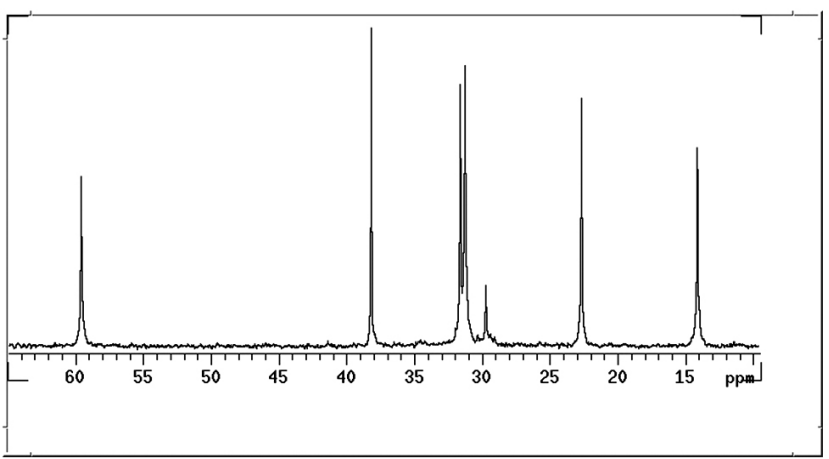

Fig. $6{ }^{13} \mathrm{C}$ NMR spectroscopy findings of Group B.

\section{CONCLUSION}

In presence of acidic free fatty acids (lactic acid-carbonic acid) esters formed with alcohols like glycerol and ethanol. High energic metabolism, oxidative stress cause acidity in retina. Electrophysiologic studies on cases with silicone oil reports increase in metabolism because of the activity in the outer and inner plexiform layers and outer segments of the photoreceptor layer due to excitotoxicity caused by increase of $\mathrm{K}^{+}$ion in retina when vitreous cavity filled with silicone oil [29].

When $\mathrm{pH}$-selective microelectrodes were used to measure $\mathrm{pH}$ in isolated vertebrate retinas, the tissue had a lower $\mathrm{pH}$ than both superfusate $[30,31]$ and choroid $[32,33]$ caused by the steady production of $\mathrm{H}^{+}$during energy metabolism. The main buffer in the brain and retina is the bicarbonate buffer system $\left(\mathrm{CO}_{2}, \mathrm{HCO}_{3}^{-}\right)[34,35]$, and $\mathrm{CO}_{2}$ is constantly produced during aerobic metabolism. Lactic acid, which also participates in $\mathrm{pH}$ buffering, is constantly produced during glycolysis [35].

It was reported that there was photoreceptor outer segment degeneration [7], reduction in the number of photoreceptor synaptic terminals in the outer 
plexiform layer and in the inner nuclear layer and affected ganglion cell layer in detached retina [36]. After reattachment of the sensory retina to the pigment epithelium, a series of complex recovery processes begin and the degenerated outer segments of photoreceptor cells begin regeneration and reorganisation [37]. All of these recovery processes need high energic metabolism. High energic metabolism causes acidity is an expected situation in Group B. But in Group A cases who mostly had been operated because of the proliferative diabetic retinopathy complications had been applied panretinal photocoagulation. In the retina, almost one-half of all the produced energy is used to maintain transmembrane ionic gradients [38]. We know that large amount of photoreceptor and pigment epithelium layer is removed in the photocoagulation area where Muller cells died and that oxygen transport could be directly from the choroid. The articles about electrophysiologic analysis of the retina after panretinal photocoagulation revealed a significant reduction in peak amplitudes of both a- and b-waves in photopic and dark-adapted conditions as early as between the multiple treatments, also in oscillatory potentials, cone single flash, and $30 \mathrm{~Hz}$ flicker responses severe reductions were showed $[39,40]$. After panretinal photocogulation, in proliferative patients $\mathrm{K}^{+}$ion excitotoxicity should not be expected in the retina that blood-retina barrier disrupted under the oxidative stress. Besides, $\mathrm{K}^{+}$ion can be removed easily through the photocoagulation area to the choroid. Also the loss of photoreceptor cells could decrease the intraretinal $\mathrm{K}^{+}$ion accumulation in such eyes. In Group A cases, high energic metabolism may not be expected. In fact, a consistent extrusion of acid could be detected even in the case of individua isolated retinal cells [41]. Then it was thought that the acidity required for esterification and epoxification can be due to ongoing metabolic activity and incease in $\mathrm{H}^{+}$ion concentration from the little amount of liquid between the retina and silicone oil that filled the vitreous cavity.

In this study, FA esters were traced in the FT-IR spectroscopy of all the hexan extracts in both groups. In Group A (opacified and gelatinous material undissolved in hexane), besides in the esterified FAs there were -OH absorption peaks around the $3200 \mathrm{~cm}^{-1}$. It can be from water emulsified by free FAs in silicone oil or secondary alchol groups resulted from reaction of carboxylic acid with epoxidised FAs. If they were free fatty acids, they would dissolve away in hexane. The -OH peaks were revealed that there were hydroxy-epoxy FAs. It is accepted that saturated or unsaturated FAs pass through the tissues surrounding the silicone oil. Unsaturated FAs with long carbon chains form epoxy esters in the presence of high oxydative stress in acid environment (e.g. in the presence of lactic acid, carboxylic acids) and the epoxy groups open up in the presence of higher oxydative stress, oxygen bridges are formed between FAs and plastification may ocur $[42,43]$. Chemically hydroxy FAs have been synthesized by peracid oxidation of unsaturated fatty acids or direct oxidation of the double bond with reagents such as hydrogen peroxide to give vicinal diols [44,45]. Occurrence of plastification in unsaturated fatty acids with long chains under high oxydative stress cause opacification and geloid appearance in silicone oils. FT-IR spectroscopy findings of gelatinous silicone material showed us the presence of both ester and hydroxyl absorbsion bands suggested the presence of hydroxy-epoxy FAs. Epoxy and hydroxy-epoxy groups in FAs can be seen in literature [45]. The examination of GC chromatographic examinations after FT-IR examination of this material, which does not dissolve in hexane could not be made.

In explanted $\mathrm{SiO}$ samples the presence of LMWC remnants were shown in some studies [22, 46,47]. A recent study showed us the presence of cyclic siloxanes (D4-D7) and their decreasing in extracted $\mathrm{SiO}$ samples dependent on the time and the size of the molecule [47]. The LMWC are believed to be able to diffuse into the surrounding tissue and cause inflamatory and toxic reactions. In the sea of silicone chemistry, we can see these LMWC producing highly lipophilic substance by hydralisation [48]. It was thought that gelatinous silicone had been formed due to plastified fatty acids bound to end group of silicone oil which contain reactive - $\mathrm{OH}$ groups. We should take into account that LMWC species carrying these-OH groups are low concentration in silicone oil and missing fatty acids can be provided by circulation into the retina.

UnsaturatedFAscan producehydroxy-epoxyFA esters in high concentration of hydrogen peroxide in low $\mathrm{pH}$ [44]. Panretinal scatter photocoagulation had been completed during surgery in Group A patients. It was well known that in cases who had been applied panretinal photocoagulation, high concentration of hydrogen peroxide was detected in the vitreous as well, after vitrectomy [49]. It is logical that lipid peroxidation of polyunsaturated FAs in the outer segment of the rod is caused by both thermal and photochemical effects of laser energy directly. Under aerobic conditions photoirradiation of melanin pigments, which are rich in retinal pigment epithelium and choroid, can generate reactive oxygen species. Furthermore, an efflux of lipid hydroperoxides to the vitreous cavity can be resulted by inflammatory cell infiltration which may contribute to the additional retinal peroxidation [50].

The retina responds to physiological and pathophysiological stimuli by the activation of phospholipases [50] and release of arachidonic acid [51]. It was reported that in diabetic patients, increase in the activities of the cytochrom p 450 (CYP) and CYP2C epoxygenase in retinal vasculature could cause epoxyeicosatrienoic acid (EET), and also astrocytes and glial cells could produce EET [52-55].

The findings had shown that the epoxy FAs could be formed in cases who had been under oxidative stress and inflammatory conditions who had had serious degeneration, in the vast area of photoreceptor and pigment epithelium layers. The low concentration of unsaturated FAs, in GC chromatography in Group A cases, supported that oxidative stress could lead to unsaturated FAs to be exhausted. GC chromatography cannot be applied to gelatinous structures. It also could be possible to establish lower rates of unsaturated fatty acid esters in remaining parts than in Group B because unsaturated fatty acid epoxy esters were the reason of the gelatinous structure which cannot be dissolved in hexan. GC-FID provides the determination of FAs and data about their relative quantity.

In case vitreous space is full of silicone oil, acidity was seen to have been formed free of tissue's metabolic activity, though not directly. FA esters that were identified in this study can be formed in the existence of acidity on the tissue or after the FAs passed to the vitreous. In case basis, it was shown that in the formation of hydroxy- epoxy FAs, extensive degeneration of the outer segments and oxidative stress of the retina could play an important role. The source of the hydroxy-epoxy FAs found in hexan extracted materials in group A cases, can be either as a product of epoxigenase activity in endothelial and glial cells and/or due to probable reaction of FAs in the vitreous space with a high concentration of $\mathrm{H}_{2} \mathrm{O}_{2}$, in the base of literature. The reactive -OH groups immediately reacts with amino acids and FAs, and may cause an opacified and gelatinous silicone oil [56]. But LMWC species with -OH groups are very low concentration. In this study, -OH peak observed in Group A cases can not belong to reactive - $\mathrm{OH}$ groups because of being connected to amino acids or FAs. We can not say that this molecule does not exist, either.

Silicone oil delivered thousands of patients to an anatomical and functional success like in our study. How long silicone can be left in eye is controversial. Serious anterior and posterior segment complications occur in cases that silicone left in eye average 30 months, however $74 \%$ anatomical success rate and $40 \%$ ambulatory vision are reported [57]. One of the last studies provided interesting insights into certain clinical situations in which silicone oil has to be maintained permanently [58]. It is reported that silicone can be left in eye until 24 mounths without serious complication [59].

Cholesterol is not a carrier for fatty acids, cholesterol is an important source of the FAs entering the retina. Unfortunately, we could not trace cholesterol in the samples. Cholesterol was not detected in none of the emulsified silicone regions. We consider that cholesterol did not take part in emulsification and so get through the silicone or little amount of cholesterol could not be detected by these methods.

In conclusion FT-IR, GC, ${ }^{1} \mathrm{H}$ NMR and ${ }^{13} \mathrm{C}$ NMR investigations were conducted on hexane extracts obtained from emulsified and water phases of polydimethyl siloxane of vitrectomized 25 cases. It had been identified that opacified and gelatinous material were formed in Group A that consists of the cases with diabetic tractional retinal detachment $(n=11)$. Silicone oil with FA esters and epoxy/hydroxy-epoxy FA esters were detected in this material and FA esters in the rest of the extract. It had also been identified that opacified and gelatinous material was not formed in Group B cases who underwent pars plana vitrectomy because of primary rhegmatogenous retinal detachment $(n=14)$ and that FA esters in silicone oil exist. Based on the knowledge that an acidic environment should be provided for the formation of them, it is thought that acidity was formed independent from the metabolic activity in the eyes with $\mathrm{SiO}$. In our study, it was investigated that, in the silicone oils removed from the retina under oxidative stress, both FA esters and hydroxy/epoxy FAs were formed. And all of these, combined with the reactive groups of the silicone causing opacified and gelatinous silicone oil. Also, again it was reported that silicone oils from retinas under oxidative stress had less unsaturated fatty acids then the other cases.

\section{ACKNOWLEDGEMENTS}

Thanks to Atilla Güngör, Prof Dr., Marmara University, Faculty of Chemistry for guidance and Gülaçtı Topçu, Prof Dr., Bezmialem Vakif University, Faculty of Pharmacy for the commnets about the ${ }^{1} \mathrm{H}$ NMR and ${ }^{13} \mathrm{C}$ NMR spectra. Thanks to Erdal Ertas, Asst. Prof Dr., TUBITAK MAM, Food Institute for GC measurements. 


\section{REFERENCES}

1. A. Tsubura, T. Yuri, K. Yoshizawa, N. Uehara, H. Takada, Histol. Histopathol. 24, 223, (2009)

2. K.R. Hegde, S.D. Varma, Ophthalmic. Res. 42, 9, (2009)

3. T. Amemiya, M. Tozu, Y. Ohashi, Jpn. J. Ophthalmol. 48, 287, (2004)

4. E.M. Semenova, C.A. Converse, Vision. Res. 43, 3063, (2003)

5. L. Bretillon, G. Thuret, S. Grégoire, N. Acar, C. Joffre, A.M. Bron, P. Gain, C.P. Creuzot-Garcher, Exp. Eye Res., 87, 521, (2008)

6. C.M. Li, B.H. Chung, J.B. Presley, Invest. Ophthalmol. Vis. Sci. 46, 2576, (2005)

7. G. Malek, C.M. Li, C. Guidry, N.E. Medeiros, C.A. Curcio, Am. J. Pathol. 162, 413, (2003)

8. K. Pascal, G. Peter, Z. Urs, R.L. Hubert, P.J. Gregor, E.K. Hanspeter, Br. J. Ophthalmol. 91, 1293, (2007)

9. A. Kubicka-Trzaska, J. Kobylarz, B. Romanowska-Dixon, Klin. Oczna. 113, 146, (2011)

10. M. Inoue, A. Iriyama, K. Kadonosono, Y. Tamaki, Y. Yanagi, Retina 29, 677, (2009)

11. A. Papp, E.B. Kiss, O. Tímár, E. Szabó, A. Berecki, J. Tóth, J. Páli, Brain Res. Bull. 74, 130, (2007)

12. U.C. Christensen, M. la Cour, Acta Ophthalmol. 90, 8, 733 (2012)

13. M. Suzuki, T. Okada, S. Takeuchi, Y. Ishii, H. Yamashita, S. Hori, Jpn. J. Ophthalmol. 35, 282, (1991)

14. K. Green, L. Cheeks, T. Slagle, H. Paul, D.K. Trask, J. Ocular Pharmacol. 9, 355, (1993)

15. E. Stefánsson, Graefes Arch. Clin. Exp. Ophthalmol. 247(2), 147, (2009)

16. K. Nakamura, M.F. Refojo, D.V. Crabtree, F.L. Leong, Invest. Ophthalmol. Vis. Sci. 31, 2059, (1990)

17. J.C. Pastor, M.I. Fernandez, M.J. del Nozal, J.B. Jonas, Am. J. Opththalmol. 143, 707, (2007)

18. J.C. Pastor, M.J. Del Nozal, P. Marinero, O. Diez, Arch. Soc. Esp. Oftalmol. 81, 13, (2006)

19. B. Bambas, C. Eckardt, E. Vowinkel, H. Kruse, Ophthalmol. 92, 663, (1995)

20. H.P. Heidenkummer, A. Kampik, S. Thierfelder, Graefe's Arch. Clin. Exp. Ophthalmol. 229, 88, (1991)

21. J.H. Dresp, D.H. Menz, Retina, 25, 902, (2005)

22. K. Nakamura, M.F. Refojo, D.V. Crabtree, J. Pastor, F.L. Leong, Invest. Ophthalmol. Vis. Sci. 32, 3007, (1991)

23. M.F. Refojo, F.L. Leong, H. Chung, N. Ueno, B. Nemiroff, F.I. Tolentino, Ophthalmology, 95, 614, (1988)

24. World Medical Association Declaration of Helsinki, 1964; Recommendations guiding physicians in biomedical research involving human subjects. Helsinki, Finland, 1964. amended in Tokyo Japan, 1975; Venice Italy, 1983; Hong Kong 1989; Somerset West South Africa, 1996; Edinburgh, Scotland, 2000; Washington, USA, 2002; Tokyo, Japan 2004; Available from URL: http:// www.wma.net/e/policy/b3.html

25. ICH Harmonised Tripartite Guideline for Good Clinical Practice (1996), Available from URL: http://www.fda.gov/oc/gcp/guidance.html

26. Directive 2001/20/EC of the European Parliament and of the Council of 4 April 2001 on the approximation of the laws, regulations and administrative provisions of the Member States relating to the implementation of good clinical practice in the conduct of clinical trials on medicinal products for human use. 2001; Official Journal of the European Communities L/21/34 1.5.2001 and the EudraCT Supporting Documentation updated 04/08/05, Available from URL: http://eudract.emea.eu.int/document.html

27. Silverstein R.M., Bassler G.C., Morrill T.C., Spectroscopic Identification of Organic Compounds. 5th edn. John Wiley and Sons, New York, 1991; pp. 91-164.

28. Willard H.H., Merrit L.L., Dean J.A., Settle F,A., Instrumental methods of analysis. 6th ed. CBS Publishers and Distributors New Delhi, 1986; pp. $1-15$.

29. M. Winter, W. Eberhardt, C. Scholz, A. Reichenbach, Invest Ophthalmol. Vis. Sci. 41(1), 256, (2000)

30. A.V. Dimitriev, S.C. Mangel, J. Physiol.522, 77, (2000)

31. A.V. Dimitriev, S.C. Mangel, J. Neurophysiol. 91, 2404, (2004)

32. L. Padnick-Silver, R.A. Linsenmeier, Vis. Neurosci. 19, 793, (2002)

33. F. Yamamoto, G.A. Borgula, R.H. Steinberg, Exp. Eye Res. 54, 685, (1992)

34. M. Chesler, Principles and practical aspects of $\mathrm{pH}$ buffering. In: $\mathrm{pH}$ and Brain Function, Kaila K, Ransom B.R. Wiley-Liss, New York: 1998; p. 11-20.
35. J. Voipio, Diffusion and buffering aspects of $\mathrm{H}^{+}$, and $\mathrm{CO}_{2}$ measurements in brain tissue. In: $\mathrm{pH}$ and Brain Function. Kaila K, Ransom BR. WileyLiss,New York: 1998. p. 45-65.

36. K. Faber, W. Kroutil, Curr. Opin. Chem. Biol. 9, 181, (2005)

37. T.I. Kim, M.S. Ha, K.C. Yoon, Korean J. Ophthalmol. 15, 118, (2001)

38. A.I.I.I. Ames, Y.Y. Li, E.C. Heher, C.R. Kimble, J. Neurosci. 12, 840, (1992)

39. C. Capoferri, M. Bagini, A. Chizzoli, A. Pece, R. Brancato, Graefes Arch. Clin. Exp. Ophthalmol. 228 (3), 232, (1990)

40. A. Messias, J.A. Filho, K. Messias, F.P. Almeida, R.A. Costa, I.U. Scott, F. Gekeler, Jorge R., Doc Ophthalmol. 124 (3), 225, (2012)

41. R.P. Malchow, M.P. Verzi, P.J. Smith, Biol. Bull. 195, 203, (1998)

42. M. Tikhonenko, T.A. Lydic, Y. Wang, Diabetes 59, 219, (2010)

43. S.H. Pine, Electrophilic Additions to unsaturated carbon (EpoxidationHydroxylation), Organic chemistry., 5th Edition California State University Los Angeles McGraw-Hill Book Company: 1987, pp. $517-$ 525.

44. P.F. Greenspan, J.R. Gall, Ind. Eng. Chem. 45, 2722, (1953)

45. M. Hamberg, G. Hamberg, Arch. Biochem. Biophys. 283, 409, (1990)

46. V.P. Gabel, A. Kampik, J. Burkhardt, Graefe's Arch. Clin. Exp. Ophthalmol. 225, 160, (1987)

47. S. Brunner, B. Izay, B. Weidinger, B. Maichel, S. Binder, Graefes Arch. Clin. Exp. Ophthalmol. 249(1), 29, (2011)

48. J.P. Kennedy, Poly(cyclosiloxane) composition and method of synthesis thereof. US Patent No. 2006/0106187 A1, 2006.

49. H. Taguchi, Y. Ogura, T. Takanashi, M. Hashizoe, Y. Honda, Invest Ophthalmol. Vis. Sci. 39, 358,(1998)

50. P. Hardy, M. Beauchamp, F. Sennlaub, F. Jr. Gobeil, L. Tremblay, B. Mwaikambo B, P. Lachapelle, S. Chemtob. Prostaglandins Leukot. Essent. Fatty Acids, 72, 301, (2005)

51. R.K. Wong, A.I. Pettit, P.A. Quinn, S.C. Jennings, J.E. Davies, L.L. Ng, Circulation 108, 1864, (2003)

52. U.R. Michaelis, N. Xia, E. Barbosa-Sicard, J.R. Falck, Fleming I. Invest. Ophthalmol. Vis. Sci. 49, 1242, (2008)

53. Z.J. Cheng, Y.F. Jiang, H. Ding, D. Severson, C.R. Triggle, Can. J. Physiol. Pharmacol. 85, 404, (2007)

54. C. Zhang, D.R. Harder, Stroke 33, 2957, (2002)

55. M.R. Metea, E.A. Newman, Exp. Physiol. 92, 635, (2007)

56. D.S. Rogers, G.J. Dorsey, . J. Chromatogr. A 892, 57, (2000)

57. G. Morphis, C. Irigoyen, A. Eleuteri, T. Stappler, I. Pearce, H. Heimann, Graefes Arch. Clin. Exp. Ophthalmol. 250(5), 645, (2012)

58. C.S. Yang, K.H. Chen, W.M. Hsu, Y.S. Li, Eye 22(2), 282, (2008)

59. M.L. Acosta, M. Kalloniatis, J. Neurochem 92(6), 1350, (2005) 